\title{
POLYMORPHISAM OF MICROSATELLITE LOCI IN MHC COMPLEX FOR AN ALBANIAN GOAT BREED
}

\author{
Anila Hoda, Lumturi Papa, Ylli Biçoku \\ Department of Animal Production, Agricultural University of Tirana (AUT), Albania \\ hodanila@yahoo.com
}

\begin{abstract}
The Major Histocompatibility Complex (MHC) plays a key role in immune response. Our study aimed at the polymorphism analysis in two microsatellite loci in the class I and II of the MHC complex for a local goat breed in Albania. The domestic goat is one of the most important livestock species in the mountainous area of Albania. Goat breeds are defined mainly by the geographic position, morphological characteristics and production performance. They are well adapted to harsh climate, diseases, poor nutrition, and extensive farming conditions. The study was carried out in 60 unrelated individuals from different villages of North Albania. Both markers were highly polymorphic. The analysis revealed a great number of alleles, 11 and 37 per class I and II, respectively. The level of heterozygosity was very high such as $86 \%$ for class I and $71 \%$ for class II. The high level of polymorphism and heterozygosity is explained by the fact that the molecules encoded by the MHC complex take part in the immune response, as well as with the overdominant selection which acts on the antigen recognition site. PIC values were higher than 0.5 . These indicated that both loci can be used as genetic markers.
\end{abstract}

Key words: MHC complex; microsatellite marker; goat; polymorphism; selection

\section{ПОЛИМОРФИЗАМ НА МИКРОСАТЕЛИТСКИТЕ ЛОКУСИ ВО КОМПЛЕКСОТ МНС КАЈ АЛБАНСКАТА РАСА КОЗИ}

\begin{abstract}
Големиот хистокомпатибилен комплекс (Major Histocompatibility Complex - MHC) има клучна улога во имуниот одговор. Целта на нашата студија беше анализа на полиморфизмот во два микросателитски локуса во класите 1 и 2 на МНС за локалната раса кози во Албанија. Домашната коза е еден од најважните видови домашни животни во планинските региони на Албанија. Расите на кози се дефинирани главно според географската локација, морфолошките карактеристики и продуктивните својства. Тие се добро адаптирани на остра клима, болести, сиромашна исхрана и екстензивни фармски услови. Студијата беше спроведена на 60 индивидуи кои не се во меѓусебно сродство, а се од различни села во северна Албанија. Обата маркера беа високо полиморфни. Анализата откри голем број алели, 11 и 37 за класите 1 и 2 соодветно. Нивото на хетерозиготност беше многу високо: $86 \%$ за класата 1 и $71 \%$ за класата 2. Високото ниво на полиморфизам и хетерозиготност се објаснува со фактот дека молекулите кодирани од страна па МНС имаат улога во имуниот одговор, како и со предоминантната селекција која дејствува за препознавање на антигените. Вредностите РIC беа повисоки од 0.5. Ова укажува на фактот дека обата локуса можат да се користат како генетски маркери.
\end{abstract}

Клучни зборови: комплекс МНС; микросателитски маркер; коза; полиморфизам; селекција

\section{INTRODUCTION}

The domestic goat is one of the most important livestock species in the mountainous area of Albania. Goat breeds are defined mainly by the geographic location, morphological characteristics and production performance.

The Major Histocompatibility Complex (MHC) plays an important role in the immune response. The loci located in the MHC region are character- ized by a high allelic diversity and the high level of polymorphism is the result of balancing selection. Polymorphic DNA markers are very useful in assessment of genetic diversity within and between breeds. Microsatellites are widely used as genetic markers for the analysis of genetic variability within and between breeds due to their high number, distribution throughout the genome and the efficacy of genotyping. There are several studies regarding the diversity of microsatellite loci in the 
MHC region of different species (Ammer et al., 1992; Ellegren et al., 1993; Gruszczyska et al., 2002; Schwaiger et al., 1993; Santucci et al., 2007)). In this study we intend to compare the level of polymorphism in two microsatellite loci, OMHC I located in the intron three of the MHC Class I, and the DRBP1 MHC II located in the second intron of the DRB1, a gene of the MHC Class II.

\section{MATERIAL AND METHODS}

\section{Sample collection and microsatellite markers}

A total of 120 randomly sampled animals representing two populations of the local goat breed in Albania were analyzed. For each population, from the field and mountainous area of origin, were sampled maximum three unrelated individuals (two females and one male) per flock. The populations are marginally farmed and indigenous. There are 2 microsatellite markers used of the MHC region from Class I and Class II.

\section{PCR condition and fragment length analysis}

Blood samples $(5 \mathrm{ml})$ were collected in EDTA vacutainer tubes. The buffy coat of leucocytes was used for DNA isolation according to phenol - chloroform extraction, proteinase $\mathrm{K}$ digestion and ethanol precipitation of DNA (Sambrook et al., 1989). All samples were genotyped for 2 microsatellite markers of the MHC complex.

The Polymerase chain reaction (PCR) amplifications were carried out using a programmable thermal cycler (Biometra). The reactions were performed in $20 \mu \mathrm{l}$ reaction volumes with $1-2 \mathrm{ng}$ of template DNA, 22 pmol of each primer, $200 \mu \mathrm{M}$ dNTP mix, 2 U of Taq DNA polymerase, buffer supplied by the enzyme manufacture. The set of primer used for the amplification of microsatrellite locus, from Class I of the MHC complex was: primer 1 5'-ATCTGGTGGGCTACAGTCCATG3' (Groth and Wetherall, 1993) and primer 2 5'GCA ATG CTT TCT AAA TTC TGA GGAA3' (Groth and Wetherall, 1993). The set of primer used for the amplification of microsatellite locus on the MHC Class II region was: primer 15 '-GAGAGTTCACTGTGCAG-3' and primer 2 5'CGTACCCAGAKTGAGTGAAGTATC-3'. The amplifications were performed as follows: an initial denaturation step at $94^{\circ} \mathrm{C}(3 \mathrm{~min})$ was followed by 32 cycles at $94^{\circ} \mathrm{C}(1 \mathrm{~min})$, and at $60^{\circ}(1 \mathrm{~min})$ and at $72^{\circ} \mathrm{C}(1 \mathrm{~min})$. The final extension step was at $72^{\circ} \mathrm{C}$ for $5 \mathrm{~min}$.

The PCR products $(0.3-0.1 \mu \mathrm{l})$ were labeled with fluorescent labeled primers and detected using $6 \%$ denaturing sequencing gel. The PCR products were separated by an electrophoresis machine (ALF).

\section{Statistical analysis}

The allele and genotype frequencies were calculated using the Genalex program (Peakall \& Smouse, 2006). The GENETIX version 4.05.2 (http://www. univ-montp2.fr// genetix/genetix/genetix $/ \mathrm{htm}$ ) was used for measuring genetic diversity within population, by the calculation of observed heterozygosity $\left(\mathrm{H}_{\mathrm{O}}\right)$ and mean unbiased estimates of gene diversity $\left(\mathrm{H}_{\mathrm{e}}\right)(\mathrm{Nei}, 1978)$, mean number of alleles (MNA) per locus, the number of private alleles (PA, alleles found in only one breed). The program FSTAT (http://www/2.until. ch.popgen.softwares/fstat.htm) was used for the calculation of corrected allele diversity (allelic richness) and inbreeding coefficient $\left(\mathrm{F}_{\mathrm{IS}}\right)$. The polymorphic information content (PIC) index for each marker was calculated according to Botstein et al. (1980).

\section{RESULTS AND DISCUSSION}

The allele and genotype frequencies of two microsatellite loci were determined in 2 populations of the Velipoja breed, located in the field (pop 1) and mountainous (pop 2) area of North Albania. Table 1 and Table 2 give the alleles and allelic frequencies for both loci in the two populations of the Velipoja goat breed, as well as for the whole population. In the population of the Velipoja breed from the field region the most frequent allele of OMHC I locus are the alleles 190 and 196 with a frequency of 0.208 , and for the population from the mountainous region the most frequent allele is 194 with a frequency of 0.196 . For the OLADRB microsatellite locus of the MHC Class II region the most frequent allele for the both population is 180 with a frequency of 0.129 and 0.186 for the field and mountainous region respectively. We have identified 11 alleles for the OMHC I locus (Table 1, Figure 1) and for the locus DRBP1 MHC II (Table 2, Figure 2) we have identified 37 alleles. 
The total number of the alleles and allele size range for each locus are presented in Table 3. The allelic size for the OMHC I ranged from 180 to 204. The fragment length of different alleles of the DRBP1 MHC II locus varied from 136 to 395.

Table 1

\begin{tabular}{|c|c|c|c|}
\hline Allele & Pop 1 & Pop 2 & Total \\
\hline 180 & 0.042 & 0.071 & 0.055 \\
\hline 184 & 0.042 & 0 & 0.023 \\
\hline 186 & 0.083 & 0.107 & 0.094 \\
\hline 188 & 0.083 & 0.161 & 0.117 \\
\hline 190 & 0.208 & 0.107 & 0.164 \\
\hline 192 & 0.139 & 0.071 & 0.109 \\
\hline 194 & 0.181 & 0.196 & 0.188 \\
\hline 196 & 0.208 & 0.143 & 0.18 \\
\hline 198 & 0.014 & 0.071 & 0.039 \\
\hline 200 & 0 & 0.054 & 0.023 \\
\hline 204 & 0 & 0.018 & 0.008 \\
\hline
\end{tabular}

Table 2

Allele frequencies of two microsatellite loci in the MHC class II in two populations of the Velipoja goat breed

\begin{tabular}{cccc|cccc}
\hline \hline Allele & Pop 1 & Pop 2 & Total & Allele & Pop 1 & Pop 2 & Total \\
\hline 136 & 0.014 & 0 & 0.007 & 194 & 0.043 & 0.014 & 0.029 \\
138 & 0.043 & 0.029 & 0.036 & 198 & 0.071 & 0.071 & 0.071 \\
156 & 0.014 & 0 & 0.007 & 246 & 0.014 & 0 & 0.007 \\
158 & 0.014 & 0 & 0.007 & 248 & 0.029 & 0.029 & 0.029 \\
162 & 0.057 & 0.014 & 0.036 & 250 & 0.014 & 0 & 0.007 \\
164 & 0.029 & 0.043 & 0.036 & 274 & 0.014 & 0.014 & 0.014 \\
166 & 0.029 & 0 & 0.014 & 292 & 0.014 & 0.014 & 0.014 \\
168 & 0.114 & 0.057 & 0.086 & 346 & 0.014 & 0 & 0.007 \\
170 & 0 & 0.043 & 0.021 & 349 & 0 & 0.029 & 0.014 \\
172 & 0.043 & 0.071 & 0.057 & 350 & 0.014 & 0 & 0.007 \\
174 & 0.043 & 0.086 & 0.064 & 351 & 0.014 & 0.029 & 0.021 \\
176 & 0.057 & 0.057 & 0.057 & 352 & 0 & 0.029 & 0.014 \\
180 & 0.129 & 0.186 & 0.157 & 381 & 0 & 0.014 & 0.007 \\
182 & 0.043 & 0.043 & 0.043 & 386 & 0 & 0.014 & 0.007 \\
186 & 0 & 0.014 & 0.007 & 387 & 0.014 & 0.029 & 0.021 \\
188 & 0.014 & 0 & 0.007 & 389 & 0 & 0.014 & 0.007 \\
190 & 0.043 & 0 & 0.021 & 390 & 0.014 & 0.014 & 0.014 \\
192 & 0.014 & 0.043 & 0.029 & 393 & 0.014 & 0 & 0.007 \\
& & & & 395 & 0.014 & 0 & 0.007 \\
\hline \hline
\end{tabular}

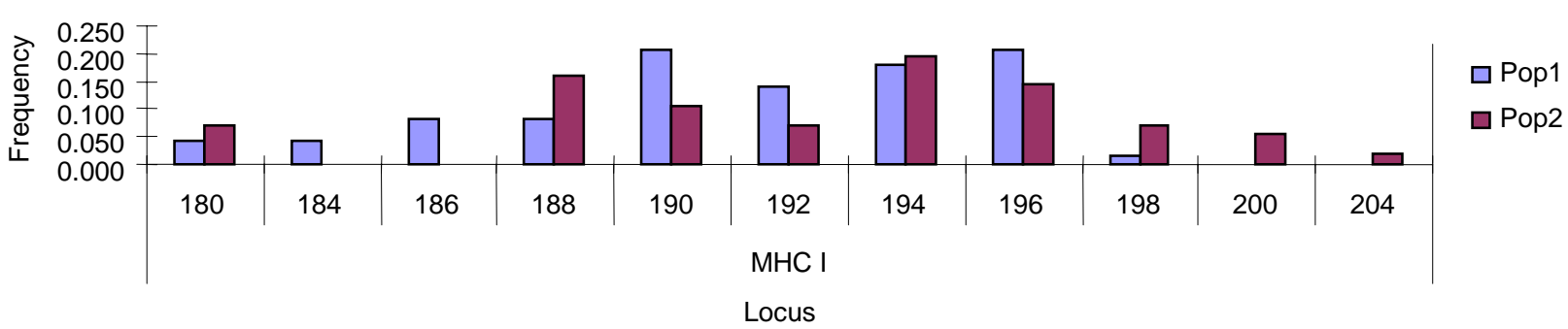

Fig. 1: Histogram of allele frequencies at the microsatellite locus in the MHC class I in both populations

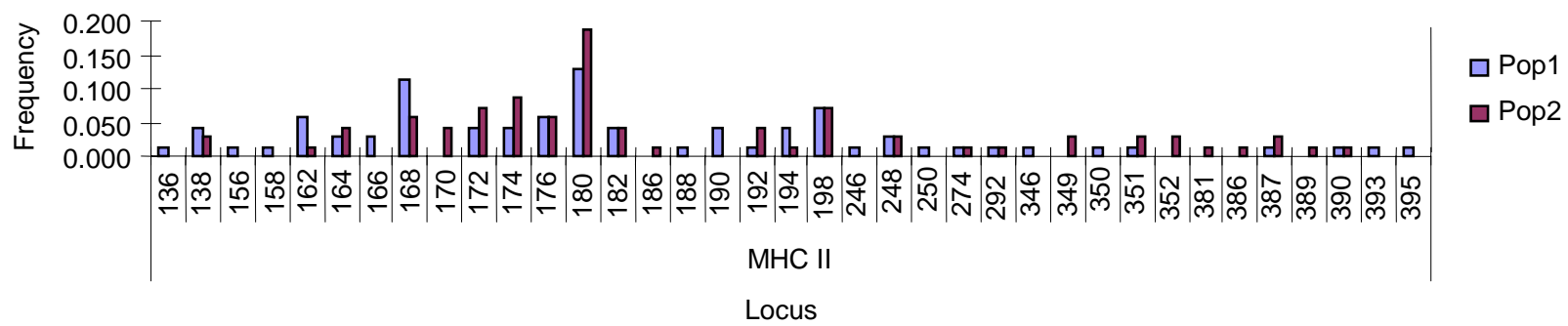

Fig. 2. Histogram of allele frequencies at the microsatellite locus in the MHC Class II in both populations

Table 3

Number of alleles (NA), allelic richness, PIC values for each of the microsatellite markers, in each population, PIC values

\begin{tabular}{l|ccccccc}
\hline \hline \multicolumn{1}{c|}{ Loci } & \multirow{2}{*}{ Allelic range } & \multirow{2}{*}{$\mathrm{H}_{\mathrm{o}}$} & PIC & $\begin{array}{c}\text { Number of alleles } \\
\text { (NA) }\end{array}$ & \multicolumn{3}{c}{ Allelic richness (AR) } \\
\hline MHC I & $180-204$ & 0.859 & 0.86 & 11 & Pop 1 & Pop 2 & Total \\
DRBP1 MHC II & $136-395$ & 0.714 & 0.94 & 37 & 8.759 & 10 & 10.019 \\
\hline \hline
\end{tabular}


Summary statistics of allelic distribution of both loci is presented in Table 3, and the histogram of allelic frequencies is presented in Figure 1 and Figure 2. A total of 48 alleles were detected over two loci in 120 individuals. In both population of the Velipoja goat breed we detected a high level of polymorphism. Allelic richness for each of the microsatellite loci in both populations is presented in Table 3. Allelic richness was 10.02 and 24.91 for the OMHC I and the OLADRB loci respectively. Both markers have high PIC values, 0.86 and 0.94 respectively.

Table 4 shows the observed and expected heterozygosity at each locus for both populations and the values of observed heterozygosity are lower than expected heterozygosity.

Table 4

\section{Summary statistics of allelic and genotypic distribution of two microsatellite loci in both populations}

\begin{tabular}{c|cc|ccc}
\hline \hline Locus & \multicolumn{2}{|c|}{ Population } & Locus & \multicolumn{2}{c}{ Population } \\
\hline MHC I & Pop 1 & Pop 2 & DRBP1 & Pop 1 & Pop 2 \\
\hline NAC II & 9.000 & 10.000 & NA & 30 & 25 \\
$\mathbf{H}_{\mathbf{0}}$ & 0.861 & 0.857 & $\mathrm{H}_{\mathrm{O}}$ & 0.829 & 0600 \\
$\mathbf{H}_{\mathbf{e}}$ & 0.861 & 0.942 & $\mathrm{H}_{\mathrm{E}}$ & 0.857 & 0.927 \\
$\mathbf{F}_{\text {IS }}$ & -0.021 & 0.019 & $\mathrm{~F}_{\mathrm{IS}}$ & 0.120 & 0.353 \\
\hline \hline
\end{tabular}

$\mathrm{H}_{\mathrm{O}}$ and $\mathrm{H}_{\mathrm{E}}$ - observed and expected heterozygosity, respectively, $\mathrm{F}_{\mathrm{IS}}$ - inbreeding coefficient.

The mean number of alleles (MNA) and the expected heterozygosity $\left(\mathrm{H}_{\mathrm{E}}\right)$ (Table 5) are useful in estimating the genetic diversity of a breed. Both populations indicated a high level of genetic diversity. Allelic richness showed high values for each locus, in each population and in total as well. The mean expected heterozygosity $\left(\mathrm{H}_{\mathrm{E}}\right)$ was similar in both populations, having a very high value. The level of the observed heterozygosity was very high: $86 \%$ for OMHC I and 71\% DRBP1 MHC II. Inbreeding values for both populations were positive. The values are given in Table $5 . \mathrm{F}_{\mathrm{IS}}$ values are 0.068 and 0.206 for pop 1 and pop 2 respectively.

In both populations we found a high level of polymorphism for both microsatellite loci. We found nine alleles of the OMHC I gene in pop 1 and ten in pop 2, and for the OLADRB locus we found 30 alleles in pop 1 and 25 in pop 2.

Goats are one of the most important livestock species in the hilly and mountainous area of Albania. They can be considered as "national richness" since $97 \%$ of the population is indigenous breeds. This is the first effort for the genetic characterrization of this breed.

Table 5

Details of 2 microsatellite loci, typed in 2 local populations

\begin{tabular}{cccccc}
\hline & $\mathrm{H}_{\mathrm{E}}$ & $\mathrm{H}_{\mathrm{O}}$ & $\mathrm{AR}$ & $\mathrm{MNA}$ & $\mathrm{F}_{\mathrm{IS}}$ \\
\hline Pop 1 & 0.89 & 0.84 & 17.702 & 19 & 0.068 \\
Pop 2 & 0.90 & 0.73 & 16.4725 & 27 & 0.206 \\
\hline
\end{tabular}

The level of the observed heterozygosity was very high for both markers. The level of heterozygosity is high in different mammal species, since these loci play an important role in the immune response to infections. The individuals that are heterozygote in any MHC locus have a better immune response than homozygote individuals (Zinkernagel et al., 1979). They graze in the pasture, the concentrate is used for a very limited period of time, during pregnancy or lactation, have a minimal veterinarian care, are adapted to the harsh climate, and are resistant to the diseases. This may be the explanation for the high degree of genetic variability. These populations represented a reservoir of allelic and genetic diversity, that have to be in consideration in breeding programs and in husbandry.

Inbreeding values for both populations were positive. Some breed specific alleles were found. A feasible reason might be the presence of population substructure within the breed, which may lead to the Wahlund's effect. Sampling was carried out in several flocks per populations.

In both populations we found a high level of polymorphism for both microsatellite loci. Different mechanisms are proposed as responsible for the maintenance of a high level of polymorphism, like the balancing selection (Paterson, 2006) or the hitchhiking effect. Both markers had high heterozygosity and PIC values displaying to be highly informative. Therefore these markers were appropriate for measuring genetic variation. 


\section{CONCLUSIONS}

- Two microsatellite markers located in the MHC complex were highly polymorphic.

- Number of alleles were higher than 5 per each marker.

- PIC values were higher than 0.5.

- Both loci can be used as genetic markers for the genetic diversity study of goat breeds.

\section{REFERENCES}

[1] Ammer, H., Schwaiger, F. W., Kammerbauer C., Gomolka M., Arriens A., Lazary S. (1992): Exonic polymorphism vs intronic simple repeat hypervariability in MHCDRB genes. Immunogenetics, 35, 332-340.

[2] Belkhir, K., Borsa, P., Chikhi Raufaste, N., Bonhomme, F. (2001): Genetix, logiciel sous Windows TM pour la génétique des populations, Laboratoire Génome, Populations, Interactions, CNRS UPR 9060, Université de Montpellier II, Montpellier France. http//www.univmontp2. $\mathrm{fr} / \sim$ genetix/genetix/genetix.htm.

[3] Botstein, D., White, R. L., Skolnick, M., and Davis, R. W. (1980): Construction of a genetic linkage map in man using restriction fragment length polymorphisms. Am. J. Hum. Genet, 32, 314-331.

[4] Ellegren, H., Davies, C. J., Anderson, L. (1993): Strong association between polymorphism in an intronic microsatellite and in the coding sequence of the Bola-Drb3 gene-implication for microsatellite stability and PCR based DRB 3 typing. Anim Genet, 34, 269-275.
[5] Goudet, J. (1995): Fstat V 2.9.3 a computer programme to calculate F-statistics http//www.unil.ch/izea/software/fstat. html. J. Hered, 8, 485-486.

[6] Groth, D. M, Wetherall, J. D. (1994): Dinucleotide repeat polymorphism, within the ovine major histocompatibility complex class I region. Anim. Genet, 25, 26.

[7] Gruszczynska, J., Charon, K. M., Swiderek, W. and Sawera, M. (2002): Microsatellite polymorphism in locus OMHC (MHC Class I) in Polish Heath Sheep and Polish Lowland Sheep (Zelanza variety). J. Appl. Genet, 2, 217222.

[8] Paterson, S. (1998): Evidence for balancing selection at the Major Histocompatibility Complex in a free living ruminant, J. Hered, 89, 289-294.

[9] Peakall, R., \& P.E. Smouse. (2006): GenAlEx 6: genetic analysis in Excel. Population genetic software for teaching and research. Molecular Ecology Notes, 6. 288-295.

[10] Sambrook, J., Fritsch, E. F., Maniatis, T. (1989): Molecular Cloning: A Laboratory Manual, $2^{\text {nd }}$ ed. Cold Spring Harbor Laboratory Press, New York, USA.

[11] Santucci, F., Ibrahim, K., M. Bruzzone, and Hewitt, G. M. (2007): Selection on MHC - linked microsatellite loci in sheep populations. Heredity, 99, 340-438.

[12] Schwaiger, F. W., Buitkamp, J., Weyersm, E., Epplen, J. T. (1993): Typing of artiodactyl Mhc-Drb genes with the help of intronic simple repeated DNA sequences. Mol. ecol, 2, 55-59.

[13] Weir, B. S. and Cockerham, C. (1984): Estimating Fstatistics for the analysis of population structure. Evolution, 38, 1358-1369.

[14] Zinkernagel, R. M., Doherty, P. C. (1979): MHCrestricted cytotoxic T cells: Study on the biological role of polymorphic major transplantation antigens determining $\mathrm{T}$ cells restriction-specificity, function and responsiveness. Adv. Immunol, 27, 151-177. 
